\title{
Competitor Density and Size Effects on Aggression and Feeding in Cutthroat Trout: Implications for Aquaculture
}

\author{
Matthew M. Wipf ${ }^{1}$ and Michael E. Barnes ${ }^{2, *}$ \\ ${ }^{1}$ Giant Springs State Fish Hatchery, Montana Department of Fish, and Wildlife, and Parks, 4801 Giant Springs Road, \\ Great Falls, Montana 59405 USA \\ ${ }^{2}$ McNenny State Fish Hatchery, South Dakota Game, Fish, and Parks 19619 Trout Loop, Spearfish, South Dakota \\ 57783 USA
}

\begin{abstract}
Competitor density and aggressive behavior influences the ability of fish to use food resources during aquaculture production. Using cutthroat trout Oncorhynchus clarkii (Richardson) from the same filial generation, this study investigated the effects of both body size and rearing density on aggression and feeding behavior. Four experiments were conducted using different numbers of both small and large trout obtained after grading. In each experiment, regardless of the number of each size of fish, small fish made significantly fewer attempts to forage in comparison to large fish. However, the number of aggressive interactions increased as small fish densities increased. These results suggest that grading and rearing differently-sized fish separately during rearing will likely maximize growth and rearing efficiencies in wild-strain cutthroat trout during hatchery rearing.
\end{abstract}

Keywords: Cutthroat trout, Oncorhynchus clarkii, aggression, aquaculture, grading.

\section{INTRODUCTION}

Competitor density is a primary factor influencing the ability of fish to defend limited resources, such as feeding territories [1, 2]. Keeley [3] found that territory size diminishes when competitor density is high in certain strains of rainbow trout Oncorhynchus mykiss (Walbaum). Resource defense theory claims that an organism will defend a resource only when the benefit of aggression is greater than the costs, and that aggression should peak at high densities allowing less-dominant organisms fewer chances to feed [4]. Thus, aggression is at its peak during elevated loading densities in hatchery rearing facilities.

In aquaculture, grading fish by size and reducing rearing densities are commonly used techniques to decrease aggression, and the occurrence of disease, and injuries [5-7]. Reduced densities also can lead to higher growth rates [5]. Noell et al. [8] observed slow growth rate with convict cichlids, Archocentrus nigrofasciatus (Günther), placed in tanks with a high density of competitors with high levels of aggression. Arnott et al. [9] reported similar findings with a specific strain of convict cichlids. Even size related sexual dimorphisms, such as in yellow perch Perca flavescens (Mitchill), can cause an increase in aggression toward food and territory [10-12]. There are costs associated with aggression, such as reduced overall fitness, feeding behavior, and growth $[8,13,14]$.

*Address correspondence to this author at the McNenny State Fish Hatchery, South Dakota Game, Fish, and Parks 19619 Trout Loop, Spearfish, South Dakota 57783 USA; Tel: 605-642-1262;

Fax: 605-642-6921; E-mail: mike.barnes@state.sd.us
Aggressive behavior is commonly reported among hatchery reared fish species [15-18]. Within a species, certain fish can be more aggressive than other fish, and aggressive behavior has been correlated to the establishment of social hierarchies, where dominant fish are more aggressive towards smaller fish lower in the pecking order $[19,20]$. In feral and wild salmonids, body size predicts hierarchy placement within the social rank [21-23]. Vehanen et al. [24] concluded that the presence of larger trout can exclude smaller fish from favorable feeding conditions which may be a factor in reducing individual growth rates of smaller fish [25]. Only a few studies encompass both use and success of guarding a resource while intruder densities are increased [26, 27].

Within a social hierarchy, dominant fish benefit by having improved foraging opportunities [28], although there are time, energy, and injury-risk costs associated with territorial defense [29]. In order to maximize food availability, a fish should defend an area in relation to the food required to survive [29]. In aquaculture facilities large fish congregate where food is most plentiful and aggressively defend that territory. Smaller fish are typically found near tailraces or furthest from the food source, likely because aggression is less in these areas [5]. The objective of this study was to evaluate aggression between differentially-sized trout in hatchery environments, in an attempt to better understand the rationale for grading fish and the effects of rearing densities.

\section{METHODS}

Cutthroat trout Oncorhynchus clarkii (Richardson) originating as eggs from Jackson National Fish Hatchery (Jackson, Wyoming, USA) were used for this study. All experiments were conducted in a rectangular fiberglass tank $(51 \mathrm{~cm}$ 
Table 1. Types and Definitions of Observed Behaviors

\begin{tabular}{|c|c|}
\hline Behavior & Definition \\
\hline \hline Eating & Fish eating administered feed \\
\hline Not eating & Fish not eating any feed \\
\hline Aggression & $\begin{array}{c}\text { Fish flashing, fighting or charging toward subservient } \\
\text { fish }\end{array}$ \\
\hline No aggression & Fish in loose schools or shoals \\
\hline Stress & $\begin{array}{c}\text { Fish flashing operculum, with raised dorsal fins, or } \\
\text { tightly schooled or shoaled. }\end{array}$ \\
\hline No stress & Fish exhibiting no stress behaviors. \\
\hline
\end{tabular}

x $63 \mathrm{~cm}$ x $38 \mathrm{~cm}$ ) with a side glass window facilitating behavioral observations (Frigid Units, Toledo, Ohio, USA). Flows of $11^{\circ} \mathrm{C}$ water were a constant $86 \mathrm{~L} / \mathrm{min}$. Experimental fish were obtained after grading of a filial generation production lot of cutthroat trout being reared at Clark's Trout Farm (Spearfish, South Dakota, USA) using a CPM-11 grader (Aquamerik St. Nicolas, Quebec, Canada). Postgraded fish were separated into either small (mean length $=$ $9.3 \mathrm{~cm}, \mathrm{SE}=0.75$ ) or large (mean length $=15.7 \mathrm{~cm}, \mathrm{SE}$ 0.62) sizes. Pelleted food used in all experiments was a 2.0 mm slow-sinking diet (Silver Cup, Nelson and Sons. Inc., Murray, Utah, USA) fed by hand at a location equidistant from each side of the tank.

Four experiments were conducted, with three replicates per experiment. Different fish were used in each replicate. In Experiment 1, one small fish and one large fish were placed in the tank. In Experiment 2, five small fish and one large fish were used. Experiment 3 consisted of one small fish and five large fish, while Experiment 4 used five fish from each size group. After placement in the tank, the experimental fish were allowed to acclimate for ten minutes. Prior to initiating a new replicate, all fish were replaced and also allowed to acclimate for ten minutes.

Experimental periods lasted ten minutes, with one food pellet fed every minute, and behavior recorded throughout the entire ten-minute period. Six main behaviors were recorded (Table 1). Aggression was defined when a fish flashed, fought, or charged a subservient fish [30-32]. Non-aggression was recorded when aggressive behavior was not observed in dominant fish. Stress was recorded if fish flashed their operculum, raised their dorsal fin, or schooled or shoaled in the corner of the observation tank [5, 33, 34]. If none of these stress signs were observed, fish were recorded as being not stressed. Eating was recorded when the presented food pellet was captured and retained. Not eating was recorded when fish were observed not eating.

The duration of aggressive and stress behaviors was recorded over the 600 -second interval. The time that each size of fish (large or small) spent exhibiting each behavior was compared using Chi square analysis, in comparison to an assumed equal allocation of time for either performing or not performing the behavior. Chi-square analysis was also used to determine the differences in the number of pellets eaten by either large or small fish in each experiment. Significance was pre-determined at $P<0.05$.

\section{RESULTS}

In experiment one, where one large fish was paired with one small fish, large fish were observed being aggressive over $65 \%$ of the time $(400 \mathrm{sec})$ which was significantly greater than that observed in the small fish (Table 2). The time spent being aggressive by large fish equaled the time small fish spent exhibiting stress behaviors, and when large fish were being non-aggressive, small fish were not showing signs of stress (Table 3). Small fish exhibited stress behaviors for a significantly longer period of time than that expected by chance. Large fish consumed significantly more pellets compared to small fish in experiment one (Table 4).

When five small fish were paired with one large fish in experiment two, the large fish again spent nearly all of the time exhibiting aggressive behaviors. Just as in experiment one, all five of the small fish were observed exhibiting stress behaviors for the same amount of time $(550 \mathrm{sec})$ that the large fish displayed aggression. Feeding during experiment two was dominated by the large fish with a mean (SE) consumption of $0.5(0.2)$ pellets, while the other pellets of feed were never consumed either by the large fish or small fish.

The five large fish in experiment three were observed displaying aggressive behaviors toward each other and the single small fish for the entire ten minute period. Both the time spent exhibiting aggressive behaviors by the large fish and the time spent exhibiting stress behaviors by the small fish were significantly different than that expected by chance. Feeding was fully dominated by the larger fish as they consumed all ten of the pellets that were presented.

With an equal number of five large and small fish in experiment four, the time spent exhibiting aggressive behavior by the large fish averaged $505 \mathrm{sec}$. This again equaled the amount of time that the small fish were observed exhibiting stress behaviors. Feeding was also again dominated by the larger fish, with no feeding occurring in the small fish.

\section{DISCUSSION}

Because a true control was not part of the experimental design of this study, the results should be interpreted with some caution. A much stronger design would have included trials with equal-sized fish, but this did not occur because of the added time constraints of incorporating these controls. Nevertheless, the results do provide insights into fish behavior, particularly as it relates to size standardization during fish rearing.

Grading fish according to size has become a nearly standard technique in commercial aquaculture facilities [35-39], and is typically conducted under the assumption that larger fish may stifle biomass gains in smaller subordinate fish $[20,40]$. In this study, both the number and size of fish affected foraging behavior. In study one, where one large fish and one small fish interacted, the larger fish dominated feeding. However, in study two, where one large fish defended the food resource against five smaller fish, foraging behavior was almost zero by either size of fish. Although there was no inherent gain of food, the larger fish still aggressively 
Table 2. Mean $( \pm$ SE) Time in Sec Spent Being Aggressive or Non-Aggressive by Large Fish in Each of Four Different Experiments ( $\mathbf{N}=3$ for Each Experiment)

\begin{tabular}{|c|c|c|c|c|c|}
\hline \multirow[b]{2}{*}{ Experiment } & \multicolumn{2}{|c|}{ Behavior } & \multirow[b]{2}{*}{ Expected } & \multirow[b]{2}{*}{$X^{2}$} & \multirow[b]{2}{*}{$P$} \\
\hline & Aggressive & Non-aggressive & & & \\
\hline 1 & 400 & 200 & 300 & 66.67 & $<0.0001$ \\
\hline 2 & 550 & 50 & 300 & 416.67 & $<0.0001$ \\
\hline 3 & 600 & 0 & 300 & 600.00 & $<0.0001$ \\
\hline 4 & 505 & 95 & 300 & 280.17 & $<0.0001$ \\
\hline
\end{tabular}

Table 3. Mean $( \pm$ SE) Time in Sec Spent Exhibiting Stress and Non-Stress Behaviors by Small Fish in each of Four Different Experiments $(\mathbf{N}=3$ for Each Experiment)

\begin{tabular}{|c|c|c|c|c|c|}
\hline Experiment & Stess & Nonstress & Expected & $\mathbf{X}^{2}$ & \multicolumn{1}{c|}{} \\
\hline \hline 1 & 400 & 200 & 300 & 66.67 & 416.67 \\
\hline 2 & 550 & 50 & 300 & 600.00 & $<.0001$ \\
\hline 3 & 600 & 0 & 300 & 280.17 & $<.0001$ \\
\hline 4 & 505 & 95 & 300 & $<.0001$ \\
\hline
\end{tabular}

Table 4. Mean $( \pm$ SE) Number of Pellets Eaten by Either Large or Small Fish Time Fish in each of Four Different Experiments. One Pellet was Presented Every 60 Secs During a 600 Sec Period ( $=3$ for each Experiment)

\begin{tabular}{|c|c|c|c|c|}
\hline Experiment & Big & Small & $\mathbf{X}^{2}$ & \multicolumn{1}{c|}{$<$} \\
\hline \hline 1 & 9.25 & 0.75 & 7.225 & $<0.0071$ \\
\hline 2 & 0.5 & 0 & 9.05 & $<0.0016$ \\
\hline 3 & 10 & 0 & 10 & $<0.0016$ \\
\hline 4 & 10 & 0 & 10 & $<$ \\
\hline
\end{tabular}

guarded the resource. Aggression from the larger fish towards the subservient fish in this study was almost always occurring regardless of food gained or lost, which also justifies size-grading to maximize production.

Several authors [35-41] have reported improvements in overall weight gain or survival of aquaculturally-reared fish that have been subjected to grading. However, the use of grading is not supported by Kamstra [39], Pyle et al. [42-44], Sunde et al. [45], Wallace and Kolbeinshavn [46], Carmichael [47], Strand and Øiestad [48], Makinen and Ruchonen [49], and Onders et al. [50]. The lack of effect by grading in the prior studies may be due to the ineffectiveness of grading to eliminate dominance hierarchies and aggression [35]. In addition, gains in biomass due to grading may only be species specific $[38,41,46,48]$.

Many features related with age, such as body size [51], number of social encounters [52], and former territory holders [53], may be correlated with social hierarchal placement during territorial defense. Similarly, several species of fish exclude smaller individuals from optimal eating locations and shelters [24], which may have an effect on correlated fitness attributes [54]. Some behaviorists propose a nonterritorial strategy for cultured salmonids when reared in high densities [55]. However, a handful of studies have ex- amined the effect of competitor densities on resource defense in salmonids in ex-situ or semi-natural environments [21, 56] and these studies were all performed with same filial generations or one age group with equally sized competitors. Keenleyside and Yamamota [56] studied smolt Atlantic salmon Salmo salar (Linnaeus) with tank densities of 3 to $44 \mathrm{fish} / \mathrm{m}^{2}$, and noted that aggression peaked near $11-\mathrm{fish} / \mathrm{m}^{2}$. Also, Kalleberg [21] revealed an increase in aggression in Baltic salmon fry when densities ranged from 3 to $25 \mathrm{fish} / \mathrm{m}^{2}$, with dominant fish disavowing their territories at the highest densities. Kaspersson et al. [27] found that as competitors grew closer in size to dominant fish, the cost of defending a resource become increasingly high. This is in agreement with the fact that large under-yearlings in their study were more exposed to yearling aggression than in smaller ones, and is consequently also in agreement with the size-assessment theory stated by Enquist and Leimar [57].

The feeding efficiency of larger cutthroat trout used in this study decreased when an increased density of small grade-off fish were added. It was only when larger fish densities were increased that foraging become more frequent. Thus, the results of this study support the prediction that the ability of a small fish to monopolize a shared resource will decrease as the number of dominant intruders increases. 
Similar results of foraging activity in salmonid culture have been found in several studies [26, 58, 59]. However, Johnson [60] found, in a specific population of rainbow trout, that although the density of competitors increased, so did foraging behavior.

Fish in this study were restricted from moving in a large tank and were subjected to different competitor densities. This may have influenced the small grade-off fish from eating some of the shared food resource. Some studies propose that similar effects can be found in-situ [61].

The small cutthroat in this study spent a lower proportion of time occupying the feeding area and had the lowest eating success. Larger fish had the highest success holding the feeding area and eating the highest proportion of the food items when small fish of the same species and filial generation were present. These results are relevant not only for salmonid aquaculture, but also have implications for the management of wild salmonid stocks [18].

\section{ACKNOWLEDGEMENTS}

We thank Mike Clark, Jill Tycz, and Sarah Zimmerman for their assistance with this study.

\section{CONFLICT OF INTEREST}

None Declared.

\section{REFERENCES}

[1] Grant JWA. Whether or not to defend? The influence of resource distribution. Mar Freshw Behav Physiol 1993; 23:137-53.

[2] Harwood AJ, Griffiths SW, Metcalfe NB, Armstrong JD. The relative influence of prior residency and dominance on the early feeding behavior of juvenile Atlantic salmon. Anim Behav 2003; 65:1141-9.

[3] Keeley ER. An experimental analysis of territory size in juvenile steelhead trout. Department of Zoology, University of British Columbia. Anim Behav 2000; 59: 477-90.

[4] Brown JL. The evolution of diversity in avian territorial systems. Wilson Bulletin 1964; 76:160-9.

[5] Piper RG. Fish hatchery management. U.S. Fish and Wildlife Service, Washington. C 1982.

[6] Winton JR. Fish health management. G. Wedemeyer, editor.:Fish Hatchery Management, $2^{\text {nd }}$ edition. American Fisheries Society, Bethesda, Maryland 2001; Pages 559-640

[7] Lategan MJ, Torpy FR, Gibson LF. Control of saprolegniosis in the eel Anguilla australis Richardson, by Aeromonas media strain A199. Aquac 2004; 240:19-27.

[8] Noell MV, Grant JWA, Carrigan JG. Effects of competitor-toresource ratio on aggression and size variation within groups of convict cichlids. Anim Behav 2005; 69: 1157-63.

[9] Arnott G, Elwood WE. Gender differences in aggressive behavior in convict cichlids. Anim Behav 2009; 78: 1221-7.

[10] Scott WB, Crossman EJ. Freshwater fishes of Canada. Bull Fisheries Res Board Canada 1973; Page184.

[11] Schott EF, Kays TB, Calbert HE. Comparative growth of male versus female yellow perch fingerling under controlled environment conditions. Selected coolwater fishes of North America. Am Fisheris Soc, Special Publication 11, Bethesda, Maryland, USA 1978; Pages 181-186

[12] Schott EF. Sexually dimorphic growth in young-of-the-year yellow perch (Perca flavescens) under controlled environmental conditions. Master's thesis. University of Wisconsin, Madison 1980.

[13] Praw JC, Grant JW. A. Optimal territory size in the convict cichlid. Behav 1999; 136:1347-63.
[14] Vollestad LA, Quinn TP. Trade-off between growth rate and aggression in juvenile coho salmon, Oncorhynchus kisutch. Anim Behav 2003; 66:561-8.

[15] Cutts CJ, Metcalfe NB, Taylor AC. Aggression and growth depression in juvenile Atlantic salmon: the consequences of individual variation in standard metabolic rate. J Fish Biol 1998; 36: 621-3.

[16] Overli O, Korzan WJ, Larson ET, Winberg S, Lepage O, Pottinger TG, Renner KJ, Summers CH. Behavioral and neuroendocrine correlates of displaced aggression in trout. Horm Behav 2004; 454:324-9.

[17] Martins CIM, Hillen B, Schrama JW, Verreth JAJ. A brief note on the relationship between redidual feed intake and aggression behavior in juveniles of African catfish Clarias gariepinus. Anim Behav Sci 2007; 111: 408-13.

[18] Seiler SM, Keeley ER. A comparision of aggressive and foraging behavior between juvenile cutthroat trout, rainbow trout and F1 hybrids. Anim Behav 2007; 74:1805-12.

[19] Gilmour KM, DiBattista JD, Thomas JB. Physiological causes and consequences of social status in salmonid fish. Integr Comp Biol 2005; 45 263-73.

[20] McIntyre DC, Healy LM, Saari M. Intraspecies aggression and monoamine levels in rainbow trout (Salmo gairdneri) fingerlings. Behavioural Neural Biol 1979; 25: 90-8.

[21] Kalleberg H. Observations in a stream tank of territoriality and competition in juvenile salmon and trout (Salmo salar L. and Salmo trutta L.). Report of the Institute of Freshwater Research, Drottningholm 1958; 39: 55-98.

[22] Sloman KA. Effects of trace metals on salmonid fish: The role of social hierarchies. Applied Anim Behav Sci 2007; 104:326-45.

[23] Sloman KA, Baker D, Winberg S, Wilson RW. Are there physiological correlates of dominance in natural trout populations? Anim Behav 2008; 76:1279-87.

[24] Vehanen T, Maki-Petays A, Aspi J, Muotka T. Intercohort competition causes spatial segregation in brown trout in artificial streams. J Fish Biol 1999; 55: 35-46.

[25] Kaspersson R, Hojesjo J. Density-dependent growth rate in an agestructured population: a field experiment on stream-dwelling brown trout Salmo trutta. J Fish Biol 2009; 74: 2196-215.

[26] Chapman MR, Kramer DL. Guarded resources: the effect of intruder number on the tactics and success of defenders and intruders. Anim Behav 1996; 52: 83-94.

[27] Kaspersson R, Hojesjo J, Pedersen S. Effects of density on foraging success and aggression in age-structured groups of brown trout. Anim Behav 2010; 79: 709-15.

[28] Labonne J, Auger M, Parade M, et al. Female preference for male body size in brown trout, Salmo trutta: is big still fashionable? Anim Behav 2009; 77: 129-37.

[29] Valdimarsson SK, Metcalfe NB. Is the level of aggression and dispersion in territorial fish dependent on light intensity? Anim Behav 2000; 31:1143-9.

[30] Nortvedt R, Holm JC. Atlantic salmon in duoculture with Arctic charr: decreased aggression enhances growth and stocking density potential. Aquac 1991; 98: 355-61.

[31] Hatlen B, Grisdale-Helland B, Helland SJ. Growth variation and fin damage in Atlantic cod (Gadus morhua L.) fed at graded levels of feed restriction. Aquac 2006; 261: 1212-21.

[32] Webb KA, Hitzfelder GM, Faulk CK, Holt GJ. Growth of juvenile cobia, Rachycentron canadum, at three different densities in a recirculating aquaculture system. Aquac 2007; 264: 232-27.

[33] Noga EJ. Fish Diseases Diagnosis and Treatment. Mosby-Year Book Inc. 1st edition Iowa State University Press 2000.

[34] Fernandes-de-Castilho M, Pottinger TG, Volpato GL. Chronic social stress in rainbow trout: Does it promote physiological habituation? Gen Comp Endocrinol 2008; 155: 141-7.

[35] Gunnes K. Effect of size grading young Atlantic salmon (Salmo salar) on subsequent growth. Aquac 1976; 9:381-6.

[36] Huet M. Textbook of fish culture, breeding, and cultivation of fish. $2^{\text {nd }}$ edition Fishing News Books, Ltd., Farnham, UK 1986. 
[37] Baardvik BM, Jobling M. Effect of size-sorting on biomass gain and individual growth rates in Arctic charr, Salvelinus alpines L. Aquac 1990; 90: 11-6.

[38] Popper DM, Golden O, Shezifi Y. Size distribution of juvenile gilthead sea bream (Sparus aurata): practical aspects. Israeli $\mathbf{J}$ Aquacul Bamidgeh 1992; 44: 147-8.

[39] Kamstra A. The effect of size grading on individual growth in eel, Anguilla anguilla, measured by individual marking. Aquac 1993; 112: 67-77.

[40] Wallat GK, Tiu LG, Wang HP, Rapp D, Leighfield C. The effects of size grading on production efficiency and growth performance of yellow perch in earthen ponds. North Am J Aquacul 2005; 67: 34-41.

[41] Lambert Y, Dutil J-D. Food intake and growth of adult Atlantic cod (Gadus morhua L.) reared under different conditions of stocking density, feeding frequency and size grading. Aquac 2001; 192 : 233-47.

[42] Pyle EA, Hammer G, Phillips, Jr AM. The effect of grading on the total weight gained by brook trout. Progressive Fish-Culturist 1961; 23: $162-8$.

[43] Pyle EA. The effect of grading on the total weight gained by brown trout. Progressive Fish-Culturist 1964; 26: 70-5.

[44] Pyle EA. The effect of grading on the total weight gained by three species of trout. Progressive Fish-Culturist 1966; 28: 29-32.

[45] Sunde LM, Imsland AK, Folkvord A, Stefansson SO. Effects of size grading on growth and survival of juvenile turbot at two temperatures. Aquac Int 1998; 6: 19-32.

[46] Wallace JC, Kolbeinshavn AG. The effect of size grading on subsequent growth in fingerling Artic charr, Salvelinus alpinus (L.). Aquac 1988; 73: 97-100.

[47] Carmichael GJ. Effects of size-grading on variation and growth in channel catfish reared at similar densities. J World Aquac Soc 1994; 25: 101-8.

[48] Strand HK, Øiestad V. Growth and effect of grading of turbot in a shallow raceway system. Aquac Int 1997; 5: 397-406.

[49] Mäkinen T, and Ruchonen K. The effect of "growth history" on the actual growth of Finnish rainbow trout (Oncorhychus mykiss Walbaum) stock. J Appl Ichthyol 1992; 8: 51-61.
[50] Onders RJ, Mims SD, Dasqupta S. Effect of size-grading and feeding frequency on growth and size variation of paddlefish, Polydon spathula, juveniles reared in ponds. J World Aquac Soc 2011; 42: 127-34.

[51] Milinski M, Parker GA. Competition for resources. In Behavioural ecology: an evolutionary approach. $3^{\text {rd }}$ edition. Krebs, J.R. \& Davies, N.B. (EDs). Oxford: Blackwell Scientific Publications 1991; Pages 137-168.

[52] Johnsson JI, Akerman A. Watch and learn: preview of the fighting ability of opponents alters contest behavior in rainbow trout. Anim Behav 1998; 56: 771-6.

[53] Eitam A, Blaustein L, Mangel M. Density and intercohort priority effects on larval Salamandra salamandra in temporary pools. Ecology 2005; 146: 36-42.

[54] Webster MS. Density dependence via intercohort competition in a coral-reef fish. Ecology 2004; 85: 986-994.

[55] Alanara A, Brannas E. Dominance in demand-feeding behavior in Arctic charr and rainbow trout: the effect of stocking density. J Fish Biol 1996; 48: 242-54.

[56] Keenleyside MHA, Yamamoto FT. Territorial behavior of juvenile Atlantic salmon (Salmo salar L.). Behav 1962; 19: 139-69.

[57] Enquist M, Leimar O. Evolution of fighting behavior: decision rules and assessment of relative strength. J Theor Biol 1983; 102: 387-410.

[58] Elliot JM. Shadow competition in wild juvenile sea-trout. J Fish Biol 2002; 61: 1268-81.

[59] Salonen A, Peuhkuri N. The effect of captive breeding on aggressive behavior of European grayling, Thymallus thymallus, in different contexts. Anim Behav 2006; 72: 819-25.

[60] Johnson JI. Group size influences foraging effort independent of predation risk: an experimental study on rainbow trout. J Fish Biol 2003; 63: 863-70.

[61] Hojesjo J, Armstrong JD, Griggiths SW. Sneeky feeding by salmon in sympatry with dominant brown trout. Anim Behav 2004; 69: $1037-41$.

() Wipf and Barnes; Licensee Bentham Open.

This is an open access article licensed under the terms of the Creative Commons Attribution Non-Commercial License (http://creativecommons.org/licenses/ by-nc/3.0/) which permits unrestricted, non-commercial use, distribution and reproduction in any medium, provided the work is properly cited. 